\title{
Byelyankacin: A Novel Melanogenesis Inhibitor Produced by Enterobacter sp. B20
}

\author{
Senji Takahashi, Hiroki Iwai, Kunio Kosaka, Toshitsugu Miyazaki, Yuko Osanai, \\ Nakako Arao, Kouichi Tanaka, Koji Nagai, Akira Nakagawa
}

Received: July 3, 2007 / Accepted: October 12, 2007

(C) Japan Antibiotics Research Association

\begin{abstract}
A novel melanogenesis inhibitor, byelyankacin (1), was isolated from the fermentation broth of a bacterial strain. The producing organism, designated B20, was identified as a member of the genus Enterobacter based on taxonomic characteristics. 1 was obtained as a white powder from the culture medium by solvent extraction and serial chromatographic purification. The structure of 1 was determined as (E)-4-(2-isocyanovinyl)phenyl $\alpha$-Lrhamnopyranoside on the basis of spectroscopic data. $\mathbf{1}$ potently inhibited mushroom tyrosinase and melanogenesis of B16-2D2 melanoma cells with $\mathrm{IC}_{50}$ value of $2.1 \mathrm{nM}$ and $30 \mathrm{nM}$, respectively.
\end{abstract}

Keywords byelyankacin, melanogenesis inhibitor, mushroom tyrosinase, B16-2D2 melanoma cell, Enterobacter sp.

Melanogenesis occurs within melanocytes and results from the melanin pigment in cells. Melanocytes, neural crestderived cells residing at the basal layer of epidermis have specialized lysosome-like organelles, termed melanosomes, which contain several enzymes that mediate the production of melanin [1]. Tyrosinase catalyzes the initial two ratelimiting reactions of this process, the hydroxylation of tyrosine to 3,4-dihydroxyphenylalanine (DOPA) and its subsequent oxidation to DOPAquinone [2, 3]. Then, tyrosinase-related proteins (TRP-1 and TRP-2) are involved in the processing of DOPAquinone to melanin polymers [4, 5]. Recently, a number of tyrosinase inhibitors from natural products have been used in cosmetics as skin-whitening agents [6 8]. Accordingly, we have screened a wide range of fermented broths for specific inhibitory effects on melanin production by melanocytes. Previously, we have reported screening program for melanogenesis inhibitors from microorganisms, using the larval haemolymph of the silkworm, Bombyx mori, in which we have reported melanoxadin [9] and melanoxazal [10] from the fermented broth of fungal strains. On the other hand, in the course of our screening for inhibitors of melannogenesis using mushroom tyrosinase and B16-2D2 melanoma cells, we discovered a new inhibitor, which we named byelyankacin (1) (Fig. 1). 1 was produced in the fermentation broth of strain B20, which was isolated from a soil sample collected in Iriomote island, Okinawa, Japan. This strain (B20) was identified as Enterobacter sp. from morphological and chemical characteristics, and named Enterobacter sp. B20. Then, the characteristics of the strain B20 were compared with the known species of Enterobacter described in Bergey's Manual of Systematic Bacteriology [11] and a microscopic picture is depicted in Fig. 2. In this
A. Nakagawa (Corresponding author), S. Takahashi, H. Iwai: Department of Biosciences, Teikyo University, 1-1 Toyosatodai, Utsunomiya, Tochigi 320-8551, Japan,

E-mail: nakagawa@nasu.bio.teikyo-u.ac.jp

K. Kosaka, T. Miyazaki, Y. Osanai: Research \& Development Center, Nagase \& Co., Ltd., 2-2-3 Murotani, Nishi-ku, Kobe 6512241, Japan
N. Arao: Pharmacovigilance Department, Astellas Pharma Inc., 3-17-1 Hasune, Itabashi-ku, Tokyo 174-8612, Japan

K. Tanaka, K. Nagai: Fermentation Research Laboratories, Drug Discovery Research, Astellas Pharma Inc., 5-2-3 Toukoudai, Tsukuba, Ibaraki 300-2698, Japan 


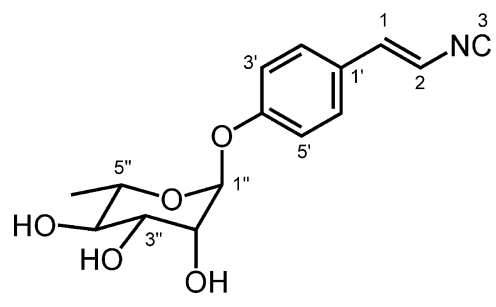

Fig. 1 Structure of byelyankacin (1).

communication, we preliminarily report the production, isolation, structure and biological activities of $\mathbf{1}$.

The producing strain identified as Enterobacter sp. B20 was found by screening a total of 2970 bacterial strains. This strain has been deposited at the International Patent Organism Depositary, the National Institute of Advanced Industrial Science and Technology, Tsukuba, Japan, as FERM BP-8266. A slant culture of the strain B20 grown on Bennett agar was inoculated into a 500-ml Erlenmeyer flask containing $100 \mathrm{ml}$ of a seed medium consisting of glucose $1.0 \%$, potato starch $2.0 \%$, polypeptone $0.5 \%$, yeast extract $0.5 \%$ and $\mathrm{CaCO}_{3} 0.4 \%$. The $\mathrm{pH}$ was adjusted to 7.0 before sterilization. Incubation was done on a rotary shaker (220 rpm) for 3 days at $28^{\circ} \mathrm{C}$. Three milliliters of the seed culture was transferred into a 500-ml Erlenmeyer flask containing $150 \mathrm{ml}$ of the production medium (glycerol $4.0 \%$, corn steep liquor $3.0 \%, \mathrm{NaNO}_{3} 0.4 \%, \mathrm{CaCO}_{3} 0.2 \%$ and $\left.\mathrm{MgSO}_{4} \cdot 7 \mathrm{H}_{2} \mathrm{O} 0.02 \%, \mathrm{pH} 5.5\right)$. The fermentation was carried out on a rotary shaker $(220 \mathrm{rpm})$ for 5 days at $28^{\circ} \mathrm{C}$. The fermentation broth (20 liters) was centrifuged and the mycelial cake was extracted with $80 \% \mathrm{Me}_{2} \mathrm{CO}$. After removal of $\mathrm{Me}_{2} \mathrm{CO}$, the aqueous solution was extracted twice with EtOAc. The supernatant was extracted with EtOAc. The EtOAc extract from the mycelium and the supernatant were combined and concentrated in vacuo to give an oily residue $(8.4 \mathrm{~g})$. The oily substance was subjected to silica gel chromatography and eluted with a stepwise gradient of $\mathrm{CHCl}_{3}-\mathrm{MeOH}(100: 1,20: 1$ and $10: 1)$. The fraction eluted by $\mathrm{CHCl}_{3}-\mathrm{MeOH}(10: 1)$ was concentrated in vacuo to give $1.2 \mathrm{~g}$ of crude powder. The powder was applied to an OASIS $^{\circledR}$ HLB extraction cartridge (Waters, $6 \mathrm{~g} / 3 \mathrm{cc}$ ) eluting with $\mathrm{MeOH}$, followed by Sephadex LH-20 column $(\mathrm{MeOH})$ to afford an active powder $(289 \mathrm{mg})$. The powder was further purified by a preparative HPLC (column: Senshu Pak PEGASIL ODS, $20 \mathrm{~mm} \times 250 \mathrm{~mm}$, Senshu Scientific Co., Ltd.) and developed with $30 \%$ acetonitrile (flow rate: $5.0 \mathrm{ml} / \mathrm{min}$; detection, UV $210 \mathrm{~nm}$ ) to give $110 \mathrm{mg}$ of $\mathbf{1}$, as a white powder. The molecular formula of $\mathbf{1}$ was established as $\mathrm{C}_{15} \mathrm{H}_{17} \mathrm{NO}_{5}$ [found $m / z 292.1187(\mathrm{M}+\mathrm{H})^{+}$, calcd. 292.1185 for $\mathrm{C}_{15} \mathrm{H}_{18} \mathrm{NO}_{5}$ ], on the basis of high-resolution FAB-MS

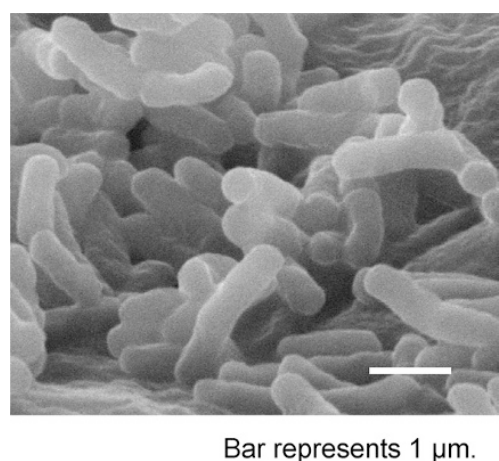

Fig. 2 Scanning electron micrograph of Enterobacter sp. B20.

and NMR spectral analyses. The physico-chemical properties of 1 were as follows: $[\alpha]_{\mathrm{D}}^{25}-142(c 0.1, \mathrm{MeOH})$, $\mathrm{UV} \lambda_{\max }^{\mathrm{MeOH}} \mathrm{nm}(\varepsilon) 210(15,200), 221(15,250)$ and 281 $(26,100)$, IR $v_{\max }(\mathrm{KBr}) \mathrm{cm}^{-1} 3413,2925,2119,1645$, 1604, 1510, 1452, 1384, 1321, 1241, 1180, 1124, 1062, 1020 , 983. 1 was soluble in DMSO, MeOH, EtOAc and $\mathrm{H}_{2} \mathrm{O}$ but insoluble in $\mathrm{CHCl}_{3}$, ether and $n$-hexane. The structure of 1 was determined by the analyses of 2D NMR experiments such as COSY, NOESY and HMBC. The ${ }^{13} \mathrm{C}-$ NMR spectrum of 1 showed 15 carbon signals, which were assigned to one methyl, eleven methines and three quaternary carbons by a DEPT experiment. The ${ }^{1} \mathrm{H}-{ }^{1} \mathrm{H}$ COSY spectrum of $\mathbf{1}$ revealed the presence of three partial structures: a trans olefin, 1,4-disubstituted benzene and a rhamnose moiety as shown in Fig. 1. Additionally, the observation of a characteristic absorption at $2119 \mathrm{~cm}^{-1}$ in the IR spectrum and ${ }^{13} \mathrm{C}-\mathrm{NMR}$ signal at $\delta_{\mathrm{C}} 164.7$ indicated clearly the presence of an isonitrile group attached to $s p^{2}$ carbon. The ${ }^{13} \mathrm{C}-\mathrm{NMR}$ spectrum of $\mathbf{1}$ is shown in Fig. 3. The ${ }^{1} \mathrm{H}$ and ${ }^{13} \mathrm{C}$ chemical shifts assignments (in $\mathrm{CD}_{3} \mathrm{OD}$ ) for 1 are indicated below: C-1 $\left(\delta_{\mathrm{C}} 137.6 / \delta_{\mathrm{H}} 6.99\right), \mathrm{C}-2\left(\delta_{\mathrm{C}}\right.$ $\left.110.6 / \delta_{\mathrm{H}} 6.52\right), \mathrm{C}-3\left(\delta_{\mathrm{C}} 164.7\right), \mathrm{C}-1^{\prime}\left(\delta_{\mathrm{C}} 128.3\right), \mathrm{C}-2^{\prime}$ and $6^{\prime}\left(\delta_{\mathrm{C}} 129.5 / \delta_{\mathrm{H}} 7.40\right), \mathrm{C}-3^{\prime}$ and $5^{\prime}\left(\delta_{\mathrm{C}} 117.8 / \delta_{\mathrm{H}} 7.06\right), \mathrm{C}-4^{\prime}$ $\left(\delta_{\mathrm{C}} 159.0\right), \mathrm{C}-1^{\prime \prime}\left(\delta_{\mathrm{C}} 99.7 / \delta_{\mathrm{H}} 5.45\right), \mathrm{C}-2^{\prime \prime}\left(\delta_{\mathrm{C}} 71.9 / \delta_{\mathrm{H}} 3.98\right)$, C-3" $\left(\delta_{\mathrm{C}} 72.2 / \delta_{\mathrm{H}} 3.82\right), \mathrm{C}-4^{\prime \prime}\left(\delta_{\mathrm{C}} 73.7 / \delta_{\mathrm{H}} 3.45\right), \mathrm{C}-5^{\prime \prime}$ $\left(\delta_{\mathrm{C}} 70.8 / \delta_{\mathrm{H}} 3.57\right), \mathrm{C}-6 "{ }^{\prime \prime}\left(\delta_{\mathrm{C}} 18.0 / \delta_{\mathrm{H}} 1.20\right)$. From these spectrometric data, the structure of $\mathbf{1}$ was elucidated to be $(E)$-4-(2-isocyanovinyl)phenyl $\alpha$-L-rhamnopyranoside, named byelyankacin.

Mushroom tyrosinase activity was determined by modified Pomeranz method [12]. In brief, the sample was mixed with the assay medium, consisting of $0.05 \mathrm{ml}$ of Ltyrosine solution $(2.5 \mathrm{mM}), 0.15 \mathrm{ml}$ of $100 \mathrm{mM}$ sodium phosphate buffer ( $\mathrm{pH}$ 6.8) in 96-well micro-plates (Corning, New York, USA), and then, with $0.05 \mathrm{ml}$ of mushroom tyrosinase solution $(600 \mathrm{U} / \mathrm{ml})$. Heat-inactivated mushroom tyrosinase was used as a control. The plates 


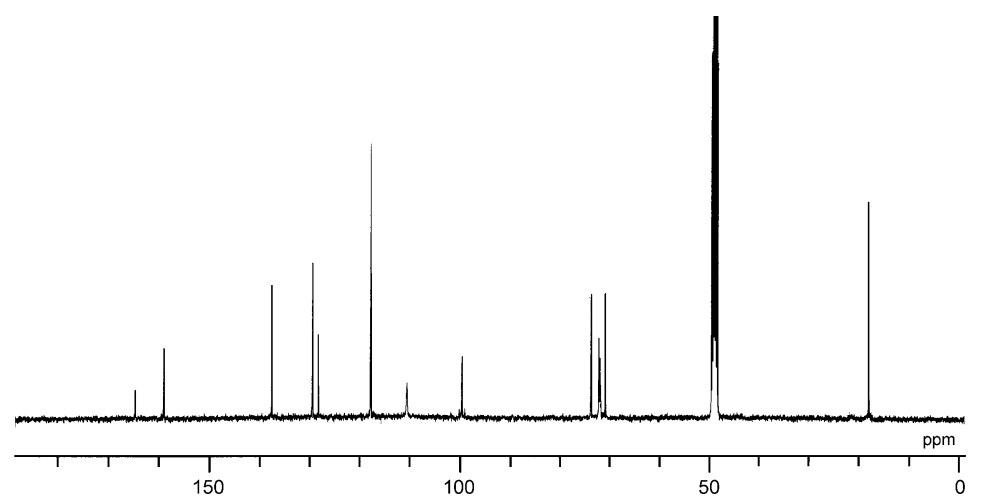

Fig. $3{ }^{13} \mathrm{C}-\mathrm{NMR}$ spectrum of byelyankacin in $\mathrm{CD}_{3} \mathrm{OD}(400 \mathrm{MHz})$.

were incubated at room temperature for 10 minutes, and the absorbance at $475 \mathrm{~nm}$ was measured with a micro-plate reader (BioRad 3550, Hercules, CA). Also, the inhibitory effect of 1 on melanogenesis was studied biochemically using a highly pigmented clone B16-2D2 mouse melanoma cells [13]. B16-2D2 cells were grown in Eagle's minimum essential medium supplemented with $10 \%$ fetal bovine serum, $4 \mathrm{mM}$ glutamine, $100 \mathrm{units} / \mathrm{ml}$ penicillin, $100 \mu \mathrm{g} / \mathrm{ml}$ streptomycin, without phenol red at $37^{\circ} \mathrm{C}$ in an atmosphere of $95 \%$ air and $5.0 \% \mathrm{CO}_{2}$. B16-2D2 cells were seeded at $10^{4}$ cells in $100 \mu 1$ of growth medium in 96-well microplates. After one day, byelyankacin was added to the culture, and cells were further incubated for 5 days. The supernatant of the culture was removed and the cells were lysed in $1.0 \%$ Triton $\mathrm{X}-100,0.1 \mathrm{~N} \mathrm{NaOH}$ solution for 20 minutes at room temperature. To calculate the melanin concentration, we measured the absorbance of the supernatants and lysates at $475 \mathrm{~nm}$ and compared it with the standard curve of synthetic melanin. The cytotoxicity of the sample was determined by measuring the protein content of the lysates by the method of Bradford protein colorimetric assay kit (BioRad, Hercules, CA).

The inhibitory effects of $\mathbf{1}$ on mushroom tyrosinase using tyrosine as a substrate, melanogenesis-suppressing activity and cyotoxicity on B16-2D2 mouse melanoma cells are shown in Table 1.1 showed strong inhibitory activity against mushroom tyrosinase with a $50 \%$ inhibitory concentration $\left(\mathrm{IC}_{50}\right)$ of $2.1 \mathrm{nM}$. It was $5,200,11,000$, 71,000 and 190,000 times more active, respectively, than hydroquinone, kojic acid, arbutin and ascorbic acid which are now being used as depigmentation agents. The $\mathrm{IC}_{50}$ of $\mathbf{1}$ against melanogenesis of B16-2D2 cells was $30 \mathrm{nM}$, and that against protein synthesis of the cells was $3.1 \mathrm{mM}$. These results suggest that byelyankacin is a highly safe tyrosinase inhibitor. Tyrosinase found in plant, animal and fungi tissue frequently differ with respect to their primary structure, size, glycosylation pattern and activation characteristics. However, all tyrosinases have in common a
Table 1 The inhibitory effects of byelyankacin (1) on mushroom tyrosinase, melanogenesis-suppressing activity and cell toxicity on B16-2D2 mouse melanoma cells

\begin{tabular}{llll}
\hline & \multicolumn{3}{c}{$\mathrm{IC}_{50}(\mathrm{M})$} \\
\cline { 2 - 4 } \multicolumn{1}{c}{ Inhibitor } & Mushroom & \multicolumn{2}{c}{ B16-2D2 mouse melanoma } \\
\cline { 3 - 4 } & tyrosinase & Melanogenesis & Protein \\
& & & \\
& & $3.0 \times 10^{-8}$ & $3.1 \times 10^{-3}$ \\
Byelyankacin & $2.1 \times 10^{-9}$ & $4.5 \times 10^{-5}$ & $7.2 \times 10^{-5}$ \\
Hydroquinone & $1.1 \times 10^{-5}$ & $3.1 \times 10^{-3}$ & $>5.0 \times 10^{-3}$ \\
Kojic acid & $2.3 \times 10^{-5}$ & $1.2 \times 10^{-4}$ & $5.2 \times 10^{-4}$ \\
Arbutin & $1.5 \times 10^{-4}$ & $3.2 \times 10^{-3}$ & n.d. \\
L-Ascorbic acid & $4.0 \times 10^{-4}$ & & \\
\hline
\end{tabular}

n.d.: not determined.

binuclear type 3 copper center within their active site [14]. 1 possesses an isocyanide functionality. It is known that isocyanide binds to copper [15]. Thus, 1 may inhibit tyrosinase activity through binding of copper within the active site. The details on the mode of action and further evaluation of 1 will be reported later.

\section{References}

1. Le Douarin NM, Dupin E, Baroffio A, Dulac C. New insights into the development of neural crest derivatives. Int Rev Cytol 138: 269-314 (1992)

2. Hearing VJ, Tsukamoto K. Enzymatic control of pigmentation in mammals. FASEB J 5: 2902-2909 (1991)

3. Hearing VJ. Mammalian monophenol monooxygenase (tyrosinase): purification, properties, and reactions catalyzed. Methods Enzymol 142: 154-165 (1987)

4. Jiménez-Cervantes C, Solano F, Kobayashi T, Urabe K, Hearing VJ, Lozano JA, García-Borrón JC. A new enzymatic function in the melanogenic pathway. The 5,6dihydroxyindole-2-carboxylic acid oxidase activity of 
tyrosinase-related protein-1 (TRP1). J Biol Chem 269: 17993-18000 (1994)

5. Jackson IJ, Chambers DM, Tsukamoto K, Copeland NG, Gilbert DJ, Jenkins NA, Hearing VJ. A second tyrosinaserelated protein, TRP-2, maps to and is mutated at the mouse slaty locus. EMBO J 11: 527-535 (1992)

6. Mishima Y. A post melanosomal era: control of melanogenesis and melanoma growth. Pigment Cell Res 2 (suppl.): 3-16 (1992)

7. Maeda K, Fukuda M. Arbutin: mechanism of its depigmenting action in human melanocyte culture. J Pharmacol Exp Ther 276: 765-769 (1996)

8. Yoshimura M, Watanabe Y, Kasai K, Yamakoshi J, Koga T. Inhibitory effect of an ellagic acid-rich pomegranate extract on tyrosinase activity and ultraviolet-induced pigmentation. Biosci Biotechnol Biochem 69: 2368-2373 (2005)

9. Hashimoto R, Takahashi S, Hamano K, Nakagawa A. A new melanin biosynthsis inhibitor, melanoxadin from fungal metabolite by using the larval haemolymph of the silkworm, Bombyx mori. J Antibiot 48: 1052-1054 (1995)

10. Takahashi S, Hashimoto R, Hamano K, Suzuki T, Nakagawa A. Melanoxazal, new melanin biosynthesis inhibitor discovered by using the larval haemolymph of the silkworm, Bombyx mori. Production, isolation, structural elucidation, and biological properties. J Antibiot 49: 513-518 (1996)

11. Grimont PAD, Grimont F. Genus Enterobacter Hormaeche and Edwards, In Bergey's Manual of Systematic Bacteriology, Vol. 2, Eds. Brenner DJ, Krieg NR \& Staley JT, pp. 661-669, Springer, New York (2005)

12. Pomerantz SH. Separation, purification, and properties of two tyrosinasese from hamster melanoma. J Biol Chem 238: 2351-2357 (1963)

13. Kosaka K, Miyazaki T, Ono M. An inhibitor of melanogenesis derived from rosemary (Rosmarinus officinalis L.). Fragrance J 9: 59-64 (2000)

14. Matoba Y, Kumagi T, Yamamoto A, Yoshitsu H, Sugiyama M. Crystallographic evidence that the dinuclear copper center of tyrosinase is flexible during catalysis. J Biol Chem 281: 8981-8990 (2006)

15. Rhames FC, Murthy NN, Karlin KD, Blackburn NJ. Isocyanide binding to the copper (I) centers of the catalytic core of peptidylglycine monooxygenase (PHMcc). J Biol Inorg Chem 6: 567-577 (2001) 